\section{Potensi Gempa Terhadap Struktur Bangunan Panggung di Lahan Basah Kalimantan Selatan}

\author{
Darmansyah Tjitradi ${ }^{1}$, Eliatun ${ }^{2}$ \\ ${ }^{1}$ Pengajar Program Studi Program Profesi Insinyur \\ Universitas Lambung Mangkurat. Konsentrasi bidang \\ keahlian teknik struktur, khususnya struktur beton \\ bertulang, permodelan komputer struktur bangunan, dan \\ assesment keruntuhan bangunan.
}

${ }^{2}$ Pengajar Program Studi Program Studi Teknik Sipil Universitas Lambung Mangkurat. Konsentrasi bidang keahlian penulis adalah manajemen rekayasa konstruksi

eliatun_tarip@ulm.ac.id

\section{Pendahuluan}

Indonesia merupakan wilayah yang sering sekali mengalami gempa bumi. Beberapa gempa besar pernah melanda Indonesia dan sebagian juga sangat berpotensi menyebabkan terjadinya tsunami. Beberapa daerah yang memiliki potensi gempa bumi besar seperti pesisir barat Sumatera, Selatan Jawa, hingga Maluku, Sulawesi dan tanah Papua. Namun terdapat satu daerah yang jarang berpotensi terjadinya gempa bumi, yaitu pulau Kalimantan. Pulau Kalimantan adalah satu-satunya wilayah di Indonesia yang sangat jarang terkena guncangan gempa bumi. Hal ini dikarenakan pulau Kalimantan memang berada kokoh di atas lempeng Eurasia dan minimnya aktifitas tektonik di permukaan tersebut, sehingga pulau Kalimantan menjadi daerah yang aman terhadap gempa bumi dan tsunami. Namun pulau Kalimantan masih beresiko terjadinya gempa bumi dikarenakan adanya endapan batuan yang lunak, dan memiliki struktur geologi yang didominasi oleh sesar dan lipatan. Secara umum sesar-sesar di Pulau Kalimantan mempunyai tiga arah, yaitu utaraselatan, barat laut-tenggara, dan barat daya-timur laut. Lipatan yang terdapat pada bagian timur Kalimantan pada umumnya berarah barat daya-
Kalimantan Selatan merupakan wilayah di Indonesia yang hampir tak tersentuh oleh potensi kerawanan bencana alam akibat aktivitas seismik dan vulkanis. Walaupun daerah Kalimantan Selatan merupakan daerah yang memiliki kondisi minim aktivitas seismik dan vulkanik sehingga aman atau termasuk wilayah gempa paling ringan (WG-1), namun kondisi lahannya umumnya merupakan lahan basah/ rawa yang memiliki daya dukung rendah/ tanah lunak yang sangat berpotensi merusak bangunan akibat terjadinya amplifikasi getaran gempa, selain itu adanya endapan batuan yang lunak, dan memiliki struktur geologi yang didominasi oleh sesar dan lipatan. Dengan menggunakan peraturan SNI 1726:2012 dan program desain spektra Indonesia milik Puskim PU dapat diperoleh grafik respon spektrum gempa rencana untuk struktur bangunan panggung di lahan basah yang mewakili 13 daerah di provinsi Kalimantan Selatan. Hasil dari penelitian ini menunjukkan bahwa grafik respon spektrum gempa rencana untuk semua daerah Kalimantan Selatan memiliki perilaku normal yaitu semakin lunak kondisi tanah maka gaya gempa dasar akan semakin besar juga, Kabupaten Balangan dan Kabupaten Tanah Laut memiliki potensi gempa terbesar dan terendah untuk semua kondisi tanah, dan daerah ini termasuk dalam Kategori Desain Seismik A dengan sistem struktur adalah sistem rangka pemikul momen biasa/menengah/ khusus atau sistem dinding struktur biasa/ khusus.

Kata kunci: gempa, respon spektrum gempa, struktur panggung, lahan basah, Kalimantan Selatan

Diajukan: 13 September 2019

Direvisi: 14 September 2019

Diterima: 16 September 2019

Dipublikasikan online:1 Oktober 2019

timur laut. Pola struktur geologi tersebut terbentuk akibat aktivitas tektonik yang terjadi sebelumnya (Rizkianingtyas T., 2018). Berdasarkan kompilasi data dari beberapa peneliti (Hamilton, 1979; Moss; Simons dkk., 2007; Hutchison, 2007), diperoleh beberapa nama sesar di Pulau Kalimantan, yaitu, Sesar Tinjia di Serawak, Sesar Adang di Kalimantan Barat, Sesar Sangkulirang di Kalimantan Timur, Sesar Paternoster di Selat Makassar. Di samping itu, juga terdapat subduksi Borneo di barat laut Sabah, subduksi Sulu di timur laut Sabah, dan subduksi Sulawesi Utara di timur Kalimantan Utara dan Kalimantan Timur (Supartoyo, 2015).

Sedangkan menurut data BMKG, 8 tahun terakhir sejak 2008 s.d. 2016 Kalimantan Selatan setidaknya telah mengalami 3 kali gempa bumi, yaitu (Zaki, 2016):

1. 05 Februari 2008: Pulau Laut, Sebuku, Pulau Sembilan, Pagatan, dan Batulicin bergetar akibat gempa bumi berkekuatan 5,8 SR dengan episentrum di kedalaman $33 \mathrm{~km}$.

2. 04 Desember 2012: Gempa bumi kembali terjadi pukul 10.13 Waktu setempat, berkekuatan 4,8 SR dengan episentrum 46 LS dan 115.40 BT 15 km Barat Laut Hulu Sungai Tengah, Kalimantan Selatan pada kedalaman 11 $\mathrm{km}$.

Cara mensitasi artikel ini:

Tjitradi, D, dan Eliatun (2019) Potensi Gempa Terhadap Struktur Bangunan Panggung di Lahan Basah Kalimantan Selatan. Buletin Profesi Insinyur 2(2) 056-062 
3. 05 April 2016: Gempa bumi kembali terjadi pukul 20.40 Waktu setempat, berkekuatan 4,1 SR dengan lokasi 1,94ㅇ LS dan 115,46ㅇ BT Barabai, Kabupaten Hulu Sungai Tengah, Kalimantan Selatan pada kedalaman 11 $\mathrm{km}$.

Selain itu selama tahun 2016 telah beberapa kali terjadi gempa bumi yang besar seperti di Taiwan $(6,4$ SR), Italia (6,2 SR), Selandia Baru (7,8 SR), Fukushima (6,9 SR), Aceh (7,8 SR), dan Chili (7,7 SR), (Liberty, 2016). Dan pada tahun 2018 Indonesia telah mengalami gempa besar di Donggala Sulawesi Tengah yang juga diikuti terjadinya tsunami yang telah memorakporandakan kota Palu (Rizkianingtyas, 2018).

Dengan berdasarkan catatan gempa pada daerah Kalimantan Selatan dan telah terjadinya peristiwa gempa bumi yang besar di beberapa negara yang dikwatirkan akan mengubah arah jalur gempa. Berdasarkan peraturan Gempa terbaru SNI 1726:2012 Kalimantan Selatan termasuk wilayah gempa paling ringan (WG 1). Walaupun daerah Kalimantan Selatan merupakan daerah yang memiliki kondisi minim aktivitas seismik dan vulkanik sehingga aman atau termasuk wilayah gempa paling ringan terhadap gempa bumi, namun daerah Kalimantan Selatan umumnya merupakan lahan basah/ rawa yang memiliki daya dukung rendah/ tanah lunak yang sangat berpotensi merusak bangunan akibat terjadinya amplifikasi getaran gempa.

Maka melalui penelitian ini sangat diperlukan sekali melakukan kajian potensi gempa pada struktur bangunan panggung di lahan basah Kalimantan Selatan berdasarkan peraturan gempa terbaru SNI 1726:2012, selain itu peraturan gempa terbaru SNI 1726:2012 juga tidak menyediakan lagi grafik respon spektrum gempa rencana seperti peraturan gempa yang terdahulu SNI 03-1726-2003. Sehingga melalui kajian ini akan tersedia grafik respon spektrum gempa rencana untuk bangunan di daerah Kalimantan Selatan, yang tentunya sangat bermanfaat bagi masyarakat luas terutama pelaku dunia konstruksi dalam mendesain bangunan di daerah lahan basah Kalimantan Selatan.

\section{Metode}

Metode penelitian yang digunakan adalah:

1) Menentukan daerah yang mewakili Kalimantan Selatan yang akan dibuat grafik respon spektrum gempa rencananya (Gambar 1).

Daerah yang dipilih untuk mewakili daerah Kalimantan Selatan adalah: Kabupaten Barito Kuala, Marabahan (Tanah Lunak), Kota Banjarmasin (Tanah Lunak), Kota Banjarbaru (Tanah Keras), Kabupaten Banjar, Martapura (Tanah Sedang dan Tanah Lunak), Kabupaten Tapin, Rantau (Tanah Sedang dan Tanah Lunak), Kabupaten Hulu Sungai Selatan, Kandangan (Tanah Sedang dan Tanah Lunak), Kabupaten Hulu Sungai Tengah, Barabai (Tanah Keras dan Tanah Lunak), Kabupaten Hulu Sungai Utara, Amuntai (Tanah Lunak), Kabupaten Balangan, Paringin (Tanah Lunak), Kabupaten Tabalong, Tanjung (Tanah Keras), Kabupaten Tanah Laut, Pelaihari (Tanah Sedang), Kabupaten Tanah Bumbu, Batulicin (Tanah Sedang), Kabupaten Kotabaru, Kotabaru (Tanah Sedang)
2) Pengolahan Data Peta Gempa daerah di Kalimantan Selatan.

Data yang diperoleh dari peta Gempa maupun melalui online website http://puskim.pu.go.id adalah parameter percepatan gempa terpetakan $\left(S_{s}\right.$ dan $\left.S_{1}\right)$ setiap kota dan kabupaten di daerah Kalimantan Selatan yang merupakan parameter awal dalam penyusunan grafik Respon Spektrum Desain Gempa.

Prosedur pembuatan grafik respon desain gempa daerah Kalimantan Selatan menurut SNI 1726:2012 adalah sebagai berikut (Himawan dkk., 2013):

- Menetapkan lokasi bangunan yang mewakili 13 daerah di Kalimantan Selatan

- Menentukan parameter percepatan gempa terpetakan $\left(\mathrm{S}_{\mathrm{s}}\right.$ dan $\left.\mathrm{S}_{1}\right)$

- Menentukan Koefisien Situs $\left(F_{a}\right.$ dan $\left.F_{v}\right)$ yang merupakan kondisi tanah bangunan pada daerah Kalimantan Selatan.

- Menghitung Parameter Percepatan Spektral Desain ( $\mathrm{S}_{\mathrm{MS}}$ dan $S_{M 1}$.

- $\mathrm{S}_{\mathrm{MS}}=\mathrm{S}_{\mathrm{s}} \cdot \mathrm{F}_{\mathrm{a}}$

- $\mathrm{S}_{\mathrm{M} 1}=\mathrm{S}_{1} \cdot \mathrm{F}_{\mathrm{v}}$

- Menentukan Koefisien Modifikasi Respon ( $S_{D S}$ dan $S_{D 1}$ )

- $S_{D S}=(2 / 3) \cdot S_{M S}$

- $S_{D 1}=(2 / 3) \cdot S_{M 1}$

- Membuat grafik respon spektrum desain gempa bangunan pada daerah Kalimantan Selatan yang ditinjau.

3) Analisis Potensi Kegempaan di setiap Daerah Kalimantan Selatan

Setelah dibuat grafik respon spektrum desain gempa setiap daerah di Kalimantan Selatan maka dapat dianalisis potensi gempa terhadap bangunan di lahan basah Kalimantan Selatan dalam bentuk grafik. Diambil kasus sebuah bangunan kantor struktur panggung beton bertulang 4 lantai seperti pada Gambar 2 yang akan dibandingkan besar gaya gempa dasar (V) yang akan bekerja pada setiap kondisi tanah di daerah Kalimantan Selatan.

Perhitungan gaya gempa dasar (V) dilakukan menggunakan Metode Statik Ekivalen dengan langkah sebagai berikut:

1. Analisis Gaya Lateral Statik Ekivalen

a) Menghitung jumlah tingkat bangunan/lapis (N)

b) Menghitung Periode Fundamental Pendekatan (Ta)

c) Menghitung Koefisien Batas Atas perioda $\left(\mathrm{C}_{\mathrm{u}}\right)$

d) Menentukan Perioda Fundamental Struktur ( $T$ ) , diambil $T_{\max }$

2. Menetapkan Kategori Resiko (Risk Category)

3. Menentukan Kategori Desain Seismik (SDC = Seismic Design Category) (KDS)

4. Menentukan Sistem Struktur

5. Menentukan Koefisien Modifikasi Respon (R)

6. Menentukan Faktor Keutamaan Gempa (le)

7. Menentukan Koefisien Respons Seismik $\left(C_{S}\right)$

8. Menghitung Gaya Gempa Dasar (V) 


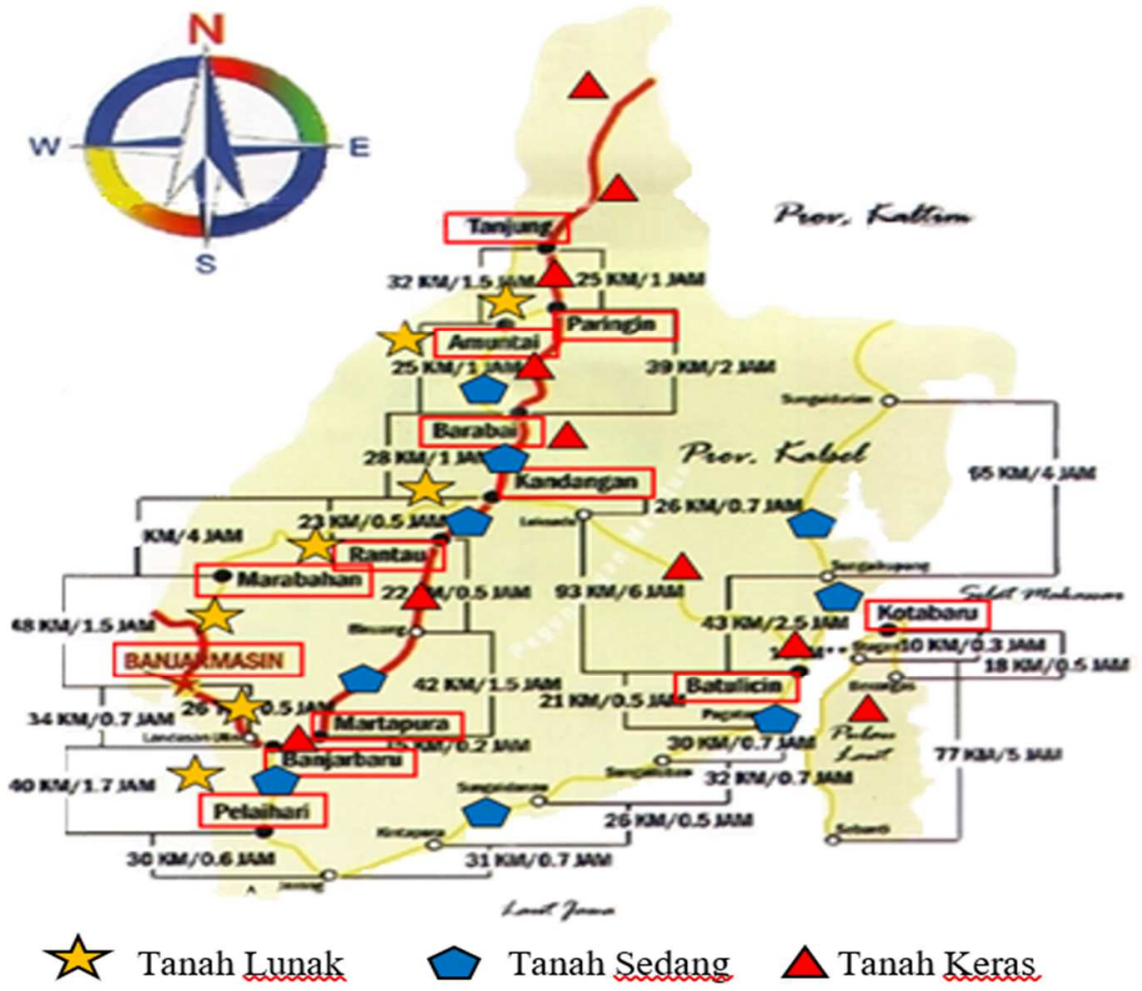

Gambar 1. Peta Daerah Kalimantan Selatan
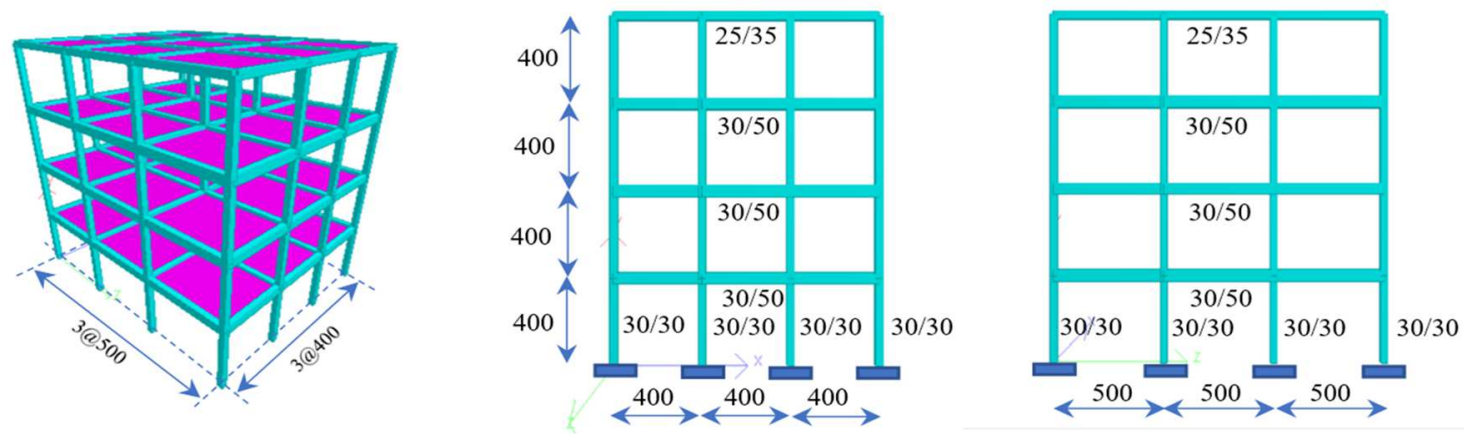

Gambar 2. Bangunan kantor struktur panggung beton bertulang 4 lantai

\section{Hasil Kerja/Analisa}

\section{1) Analisis Respon Spektrum Gempa Daerah Kalimantan}

\section{Selatan}

Hasil dari analisis respons spektrum gempa untuk 13 daerah yang mewakili daerah Kalimantan Selatan yang dibuat dengan menggunakan website http://puskim.pu.go.id dapat dilihat pada Gambar 3 s.d. 15.

\section{2) Analisis Gaya Gempa Dasar Daerah Kalimantan Selatan}

Hasil dari analisis gaya gempa dasar terhadap model struktur bangunan di daerah Kalimantan Selatan yang menggunakan metode statik ekivalen dapat dilihat pada Tabel 1 dan Gambar 16.

Dari hasil analisis gaya gempa dasar menurut SNI 1726:2012 dapat diketahui bahwa kota Banjarmasin memiliki Kategori Desain Seismik KDS $=$ A dan sistem struktur yang diijinkan adalah Sistem Rangka Pemikul Momen Biasa/ Menengah/ Khusus atau Sistem Dinding Struktur Biasa/ Khusus. Selain itu dari Tabel 1 dapat diketahui bahwa Kabupaten Balangan dan Kabupaten Tanah Laut memiliki potensi gempa terbesar dan terendah untuk semua kondisi tanah. 


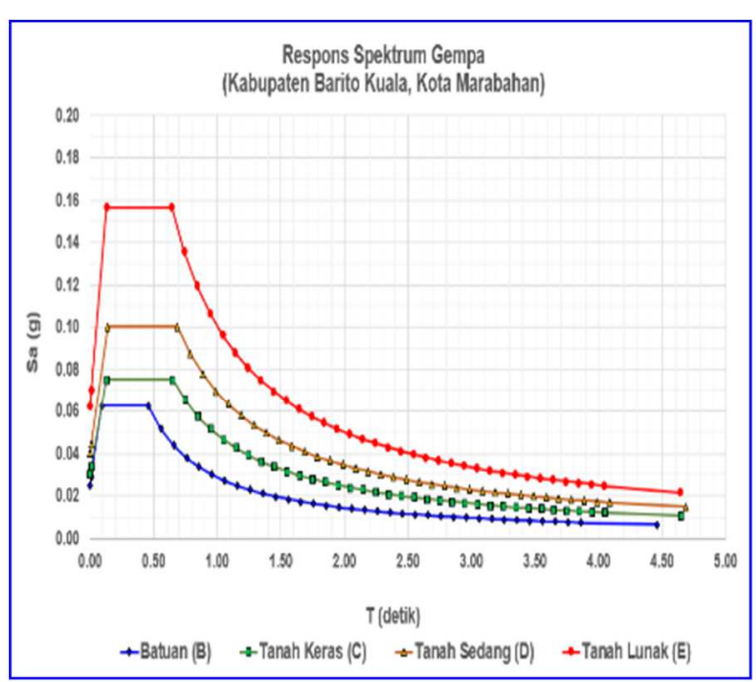

Gambar 3. Grafik Respons Spektrum Gempa Kabupaten Barito Kuala, Marabahan

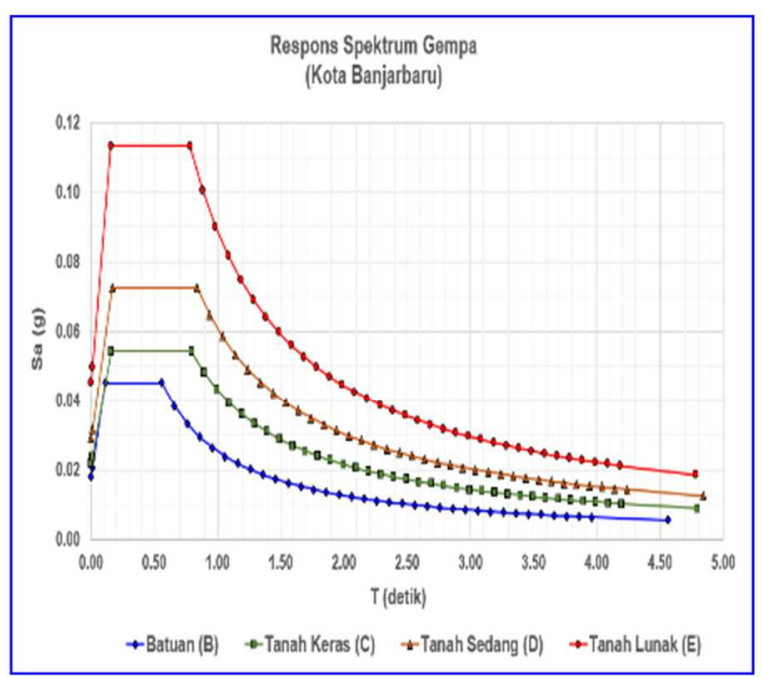

Gambar 5. Grafik Respons Spektrum Gempa Kota Banjarbaru

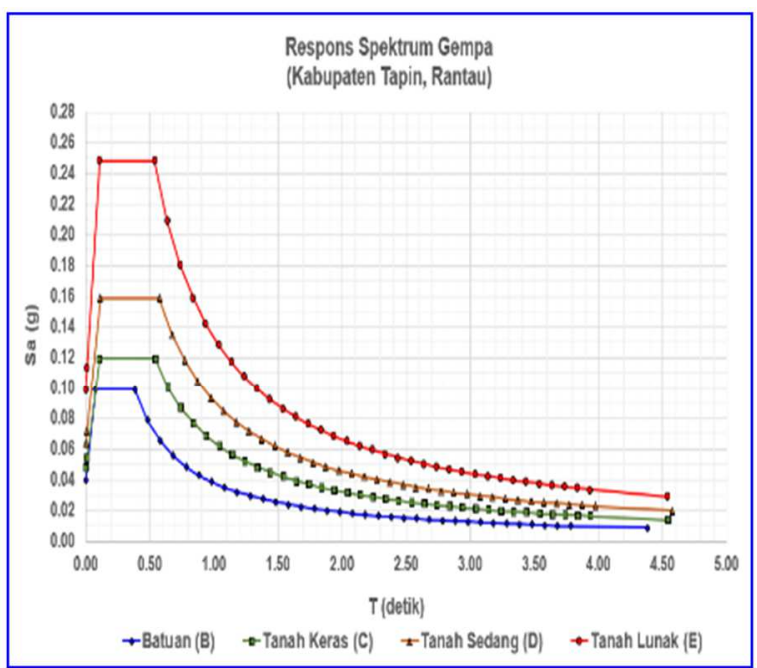

Gambar 7. Grafik Respons Spektrum Gempa Kabupaten Tapin, Rantau

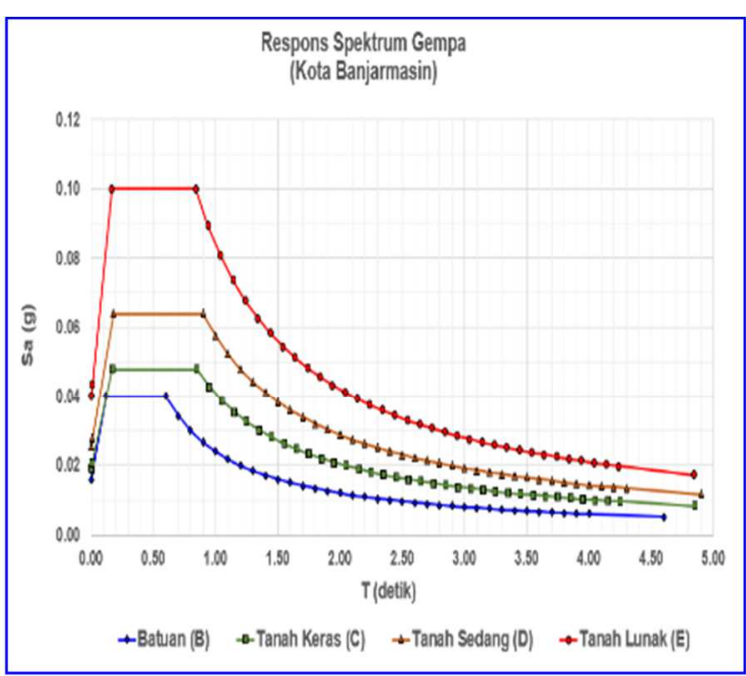

Gambar 4. Grafik Respons Spektrum Gempa Kota Banjarmasin

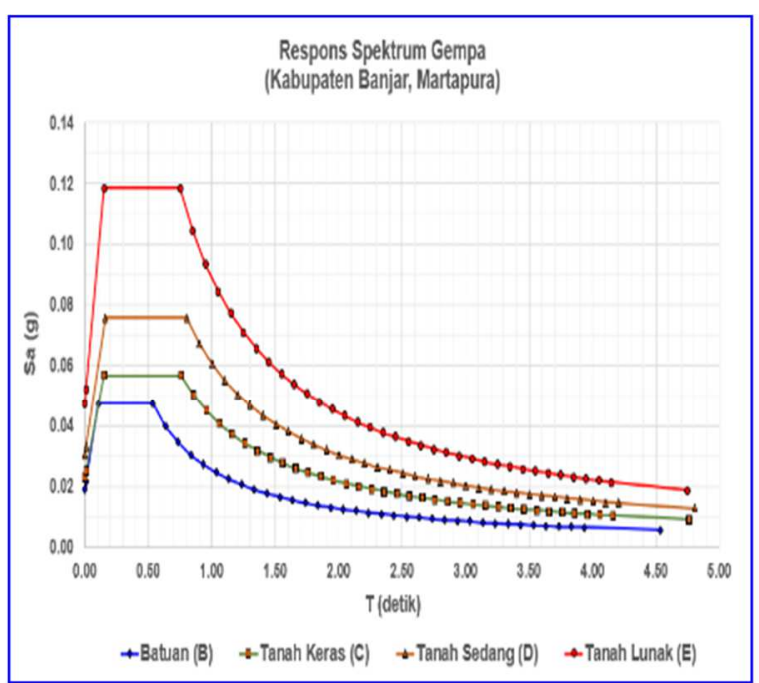

Gambar 6. Grafik Respons Spektrum Gempa Kabupaten Banjar, Martapura

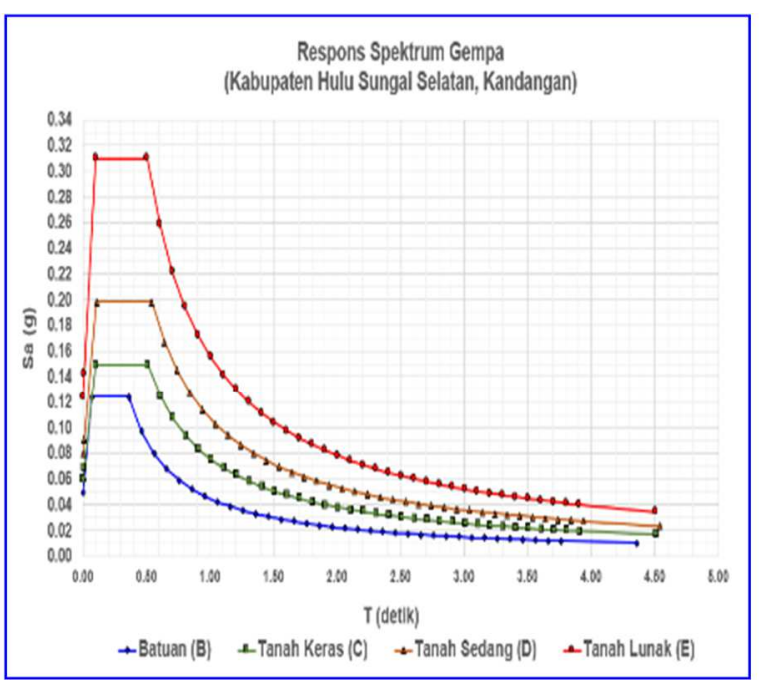

Gambar 8. Grafik Respons Spektrum Gempa Kabupaten HSS, Kandangan 


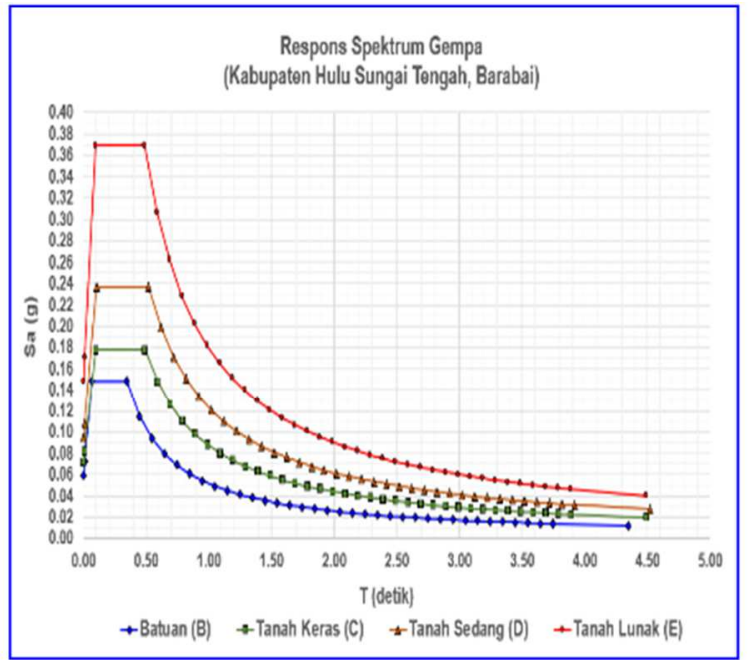

Gambar 9. Grafik Respons Spektrum Gempa Kabupaten HST, Barabai

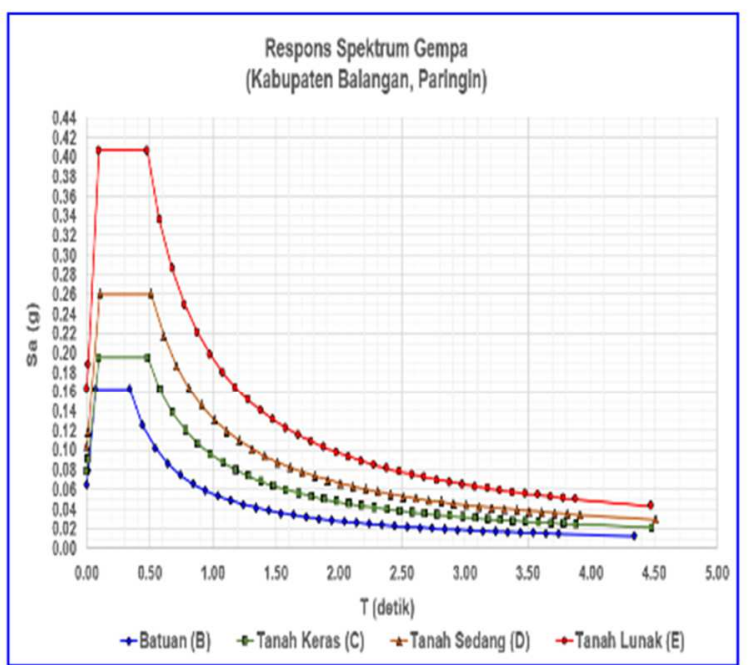

Gambar 11. Grafik Respons Spektrum Gempa Kabupaten Balangan, Paringin

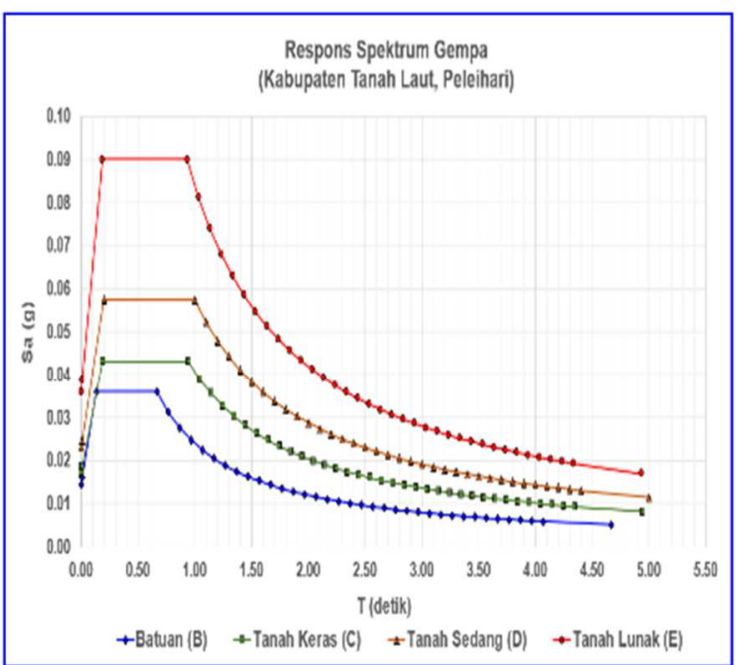

Gambar 13. Grafik Respons Spektrum Gempa Kabupaten Tanah Laut, Peleihari

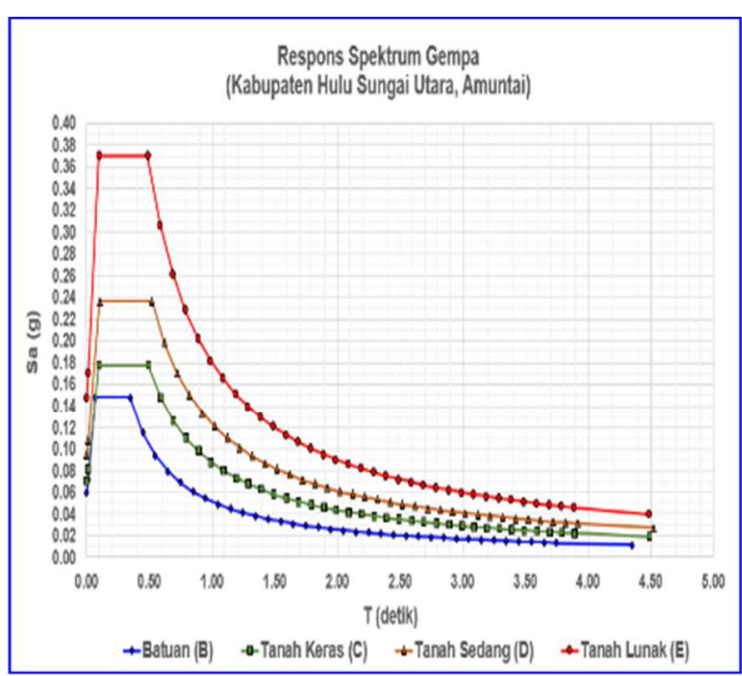

Gambar 10. Grafik Respons Spektrum Gempa Kabupaten HSU, Amuntai

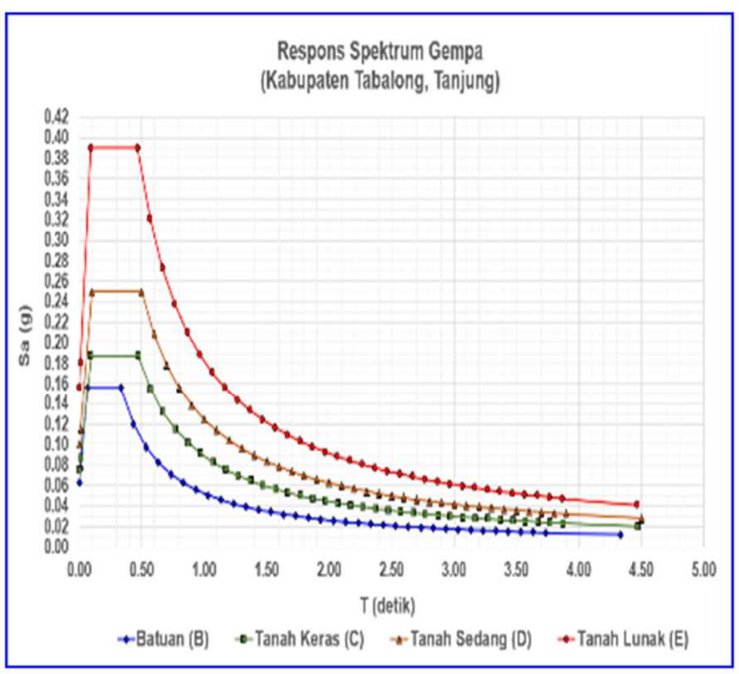

Gambar 12. Grafik Respons Spektrum Gempa Kabupaten Tabalong, Tanjung

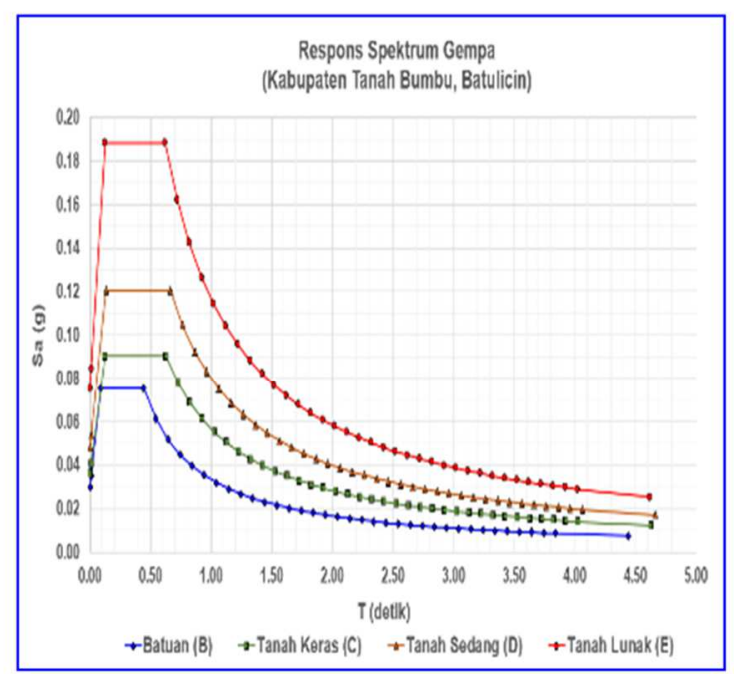

Gambar 14. Grafik Respons Spektrum Gempa Kabupaten Tanah Bumbu, Batulicin 


\section{Kesimpulan}

Dari hasil analisis gempa yang menggunakan metode statik ekivalen terhadap 13 daerah Kalimantan Selatan dapat disimpulkan sebagai berikut:

1) Telah diperoleh grafik respon spektrum gempa rencana yang mewakili 13 daerah di Kalimantan Selatan.

2) Kabupaten Balangan memiliki potensi gempa terbesar dengan gaya gempa dasar terbesar dan terendah adalah Kabupaten Tanah Laut untuk semua kondisi tanah.

3) Grafik respon spektrum gempa rencana untuk semua daerah Kalimantan Selatan memiliki perilaku normal (tidak terdapat anomali), hal ini berarti bahwa semakin lunak kondisi tanah maka gaya gempa dasar akan semakin besar juga.

4) Daerah Kalimantan Selatan termasuk dalam Kategori Desain Seismik A.

5) Sistem struktur untuk struktur di daerah Kalimantan Selatan adalah Sistem Rangka Pemikul Momen Biasa/ Menengah/ Khusus atau Sistem Dinding Struktur Biasa/ Khusus.

\section{Ucapan Terimakasih}

Ucapan terima kasih kepada Fakultas Teknik ULM yang telah memberikan bantuan dana dalam melaksanakan penelitian ini.

\section{Referensi}

Himawan I, dkk.,(2013) Aplikasi SNI Gempa 1726:2012, Semarang (2013).

Liberty, J (2016) Tahunnya Gempa Bumi Dahsyat, http://www.suara.com/tekno/ 2016/ 12/ 27/

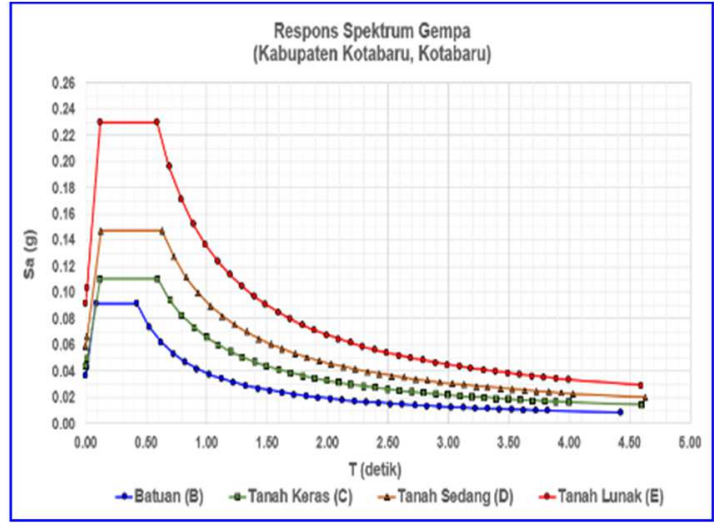

Gambar 15. Grafik Respons Spektrum Gempa Kabupaten Kotabaru, Kotabaru

203700/2016-tahunnya-gempa-bumi-dasyat, diakses 13 Januari 2017) .

Rizkianingtyas, T (2018), Jarang Terjadi Gempa, Benarkah Pulau Kalimantan Sepenuhnya Aman dari Gempa Bumi?, http://travel.tribunnews.com/ 2018/ 10/01/jarang-terjadi-gempa-benarkah-pulaukalimantan -sepenuhnya- aman- dari- gempa-bumi? page $=3$, diakses 28 Februari 2019).

SNI 1726 (2012) Tata Cara Perencanaan Ketahanan Gempa untuk Struktur Bangunan Gedung dan Non Gedung, BSN.

Supartoyo (2015) Mitos Tiada Gempa Di Kalimantan http://geomagz.geologi.esdm.go.id/mitos-tiadagempa-di-kalimantan/, diakses 28 Februari 2019).

Zaki (2016) Sejarah Gempa Bumi di Kalimantan Selatan 2008- 2016, http://banjarmasinpedia.blogspot. co.id/2016/04/gempa-bumi-kalimantan-selatan. html, diakses 13 Januari 2017).

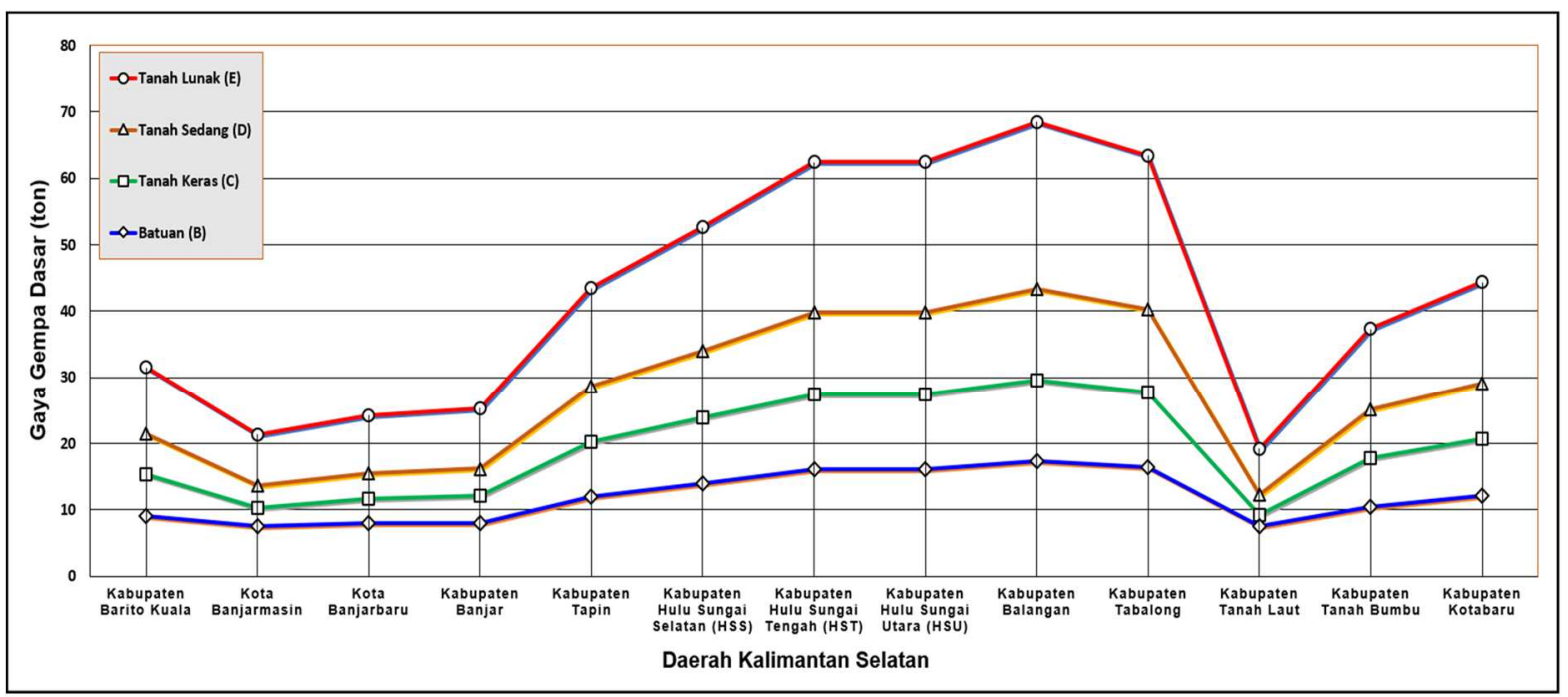

Gambar 16. Grafik Gaya Gempa Dasar daerah Kalimantan Selatan 
Tabel 1. Hasil Analisis Gaya Gempa Dasar Daerah Kalimantan Selatan

\begin{tabular}{|c|c|c|c|c|c|c|c|}
\hline \multirow{2}{*}{ No } & \multirow{2}{*}{ Nama Daerah } & \multirow{2}{*}{ Lokasi } & \multicolumn{4}{|c|}{ Gaya Gempa Dasar (V) (ton) } & \multirow{2}{*}{ Keterangan Kondisi Tanah } \\
\hline & & & Batuan (B) & Tanah Keras $(\mathbf{C})$ & Tanah Sedang (D) & Tanah Lunak (E) & \\
\hline 1 & Kabupaten Balangan & $\begin{array}{l}\text { Kantor Bupati Balangan } \\
\text { di Paringin }\end{array}$ & 17.402 & 29.583 & 43.385 & 68.505 & Tanah Lunak \\
\hline 2 & Kabupaten Tabalong & $\begin{array}{l}\text { Kantor Bupati Tabalong } \\
\text { di Tanjung } \\
\end{array}$ & 16.354 & 27.801 & 40.363 & 63.445 & Tanah Keras \\
\hline 3 & Kabupaten Hulu Sungai Tengah (HST) & Stadion Murakata Barabai & 16.144 & 27.445 & 39.767 & 62.443 & $\begin{array}{l}\text { Tanah Lunak } \\
\text { Tanah Keras } \\
\end{array}$ \\
\hline 4 & Kabupaten Hulu Sungai Utara (HSU) & Tugu Itik Amuntai & 16.144 & 27.445 & 39.767 & 62.443 & Sangat Lunak \\
\hline 5 & Kabupaten Hulu Sungai Selatan (HSS) & Tugu Dodol Kandangan & 14.047 & 23.880 & 33.968 & 748.490 & $\begin{array}{c}\text { Perbatasan dengan Tapin }=\text { Tanah Lunak } \\
\text { Tanah Sedang }\end{array}$ \\
\hline 6 & Kabupaten Kotabaru & Kantor Bupati Tanah Bumbu di Batulicin & 12.160 & 20.673 & 29.185 & 44.357 & Tanah Sedang \\
\hline 7 & Kabupaten Tapin & Pasar Raya Rantau & 11.951 & 20.316 & 28.682 & 43.461 & $\begin{array}{c}\text { Tanah Lunak } \\
\text { Tanah Sedang } \\
\end{array}$ \\
\hline 8 & Kabupaten Tanah Bumbu & $\begin{array}{l}\text { Kantor Bupati Tanah Bumbu } \\
\text { di Batulicin }\end{array}$ & 10.483 & 17.821 & 25.159 & 37.365 & $\begin{array}{c}\text { Tanah Keras } \\
\text { Tanah Sedang } \\
\end{array}$ \\
\hline 9 & Kabupaten Barito Kuala & Kantor PDAM Marabahan & 9.015 & 15.326 & 21.442 & 31.565 & Sangat Lunak \\
\hline 10 & Kabupaten Banjar & Alun-Alun Martapura & 7.967 & 12.147 & 16.196 & 25.306 & $\begin{array}{c}\text { Perbatasan Banjarbaru }=\text { Tanah Sedang } \\
\text { Perbatasan dengan Banjarmasin }=\text { Tanah Lunak }\end{array}$ \\
\hline 11 & Kota Banjarbaru & $\begin{array}{c}\text { Universitas Achmad Yani } \\
\text { Banjarbaru } \\
\end{array}$ & 7.967 & 11.634 & 15.512 & 24.237 & Tanah Keras \\
\hline 12 & Kota Banjarmasin & Taman Siring 0 Kilometer & 7.548 & 10.265 & 13.687 & 21.385 & Sangat Lunak \\
\hline 13 & Kabupaten Tanah Laut & $\begin{array}{l}\text { Kantor Bupati Kabupaten Tanah Laut } \\
\text { di Peleihari }\end{array}$ & 7.548 & 9.239 & 12.318 & 19.247 & Tanah Sedang \\
\hline
\end{tabular}

Keterangan:

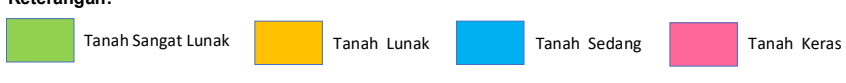

